\title{
JAWABAN SOAL UTS 2018/2019 HAKI
}

Sigit Toni Nurcahyo

\author{
155100072
}

Fakultas Komputer, 448757158

sigittoninurcahyo.student@umitra.ac.id

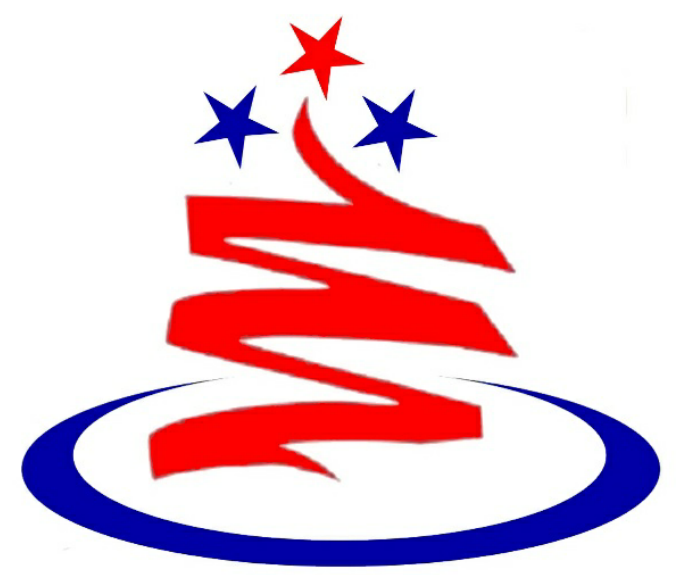

UnIVERSITAS mITRA InDONESIA 
A. STUDI KASUS (SK)

Pertanyaan Type C :

Penjelasan tentang produk kelompok PARSUT.

Jawaban :

Nama merk : REOG

Yang terinspirasi dari kebudayaan yang berasal dari jawa, yang tujuan nya untuk mengenalkan produk asli indonesia dan melestarikan kebudayaan indonesia.

Paten :

Dibuat oleh tiga pemuda asal indonesia yang bernama sigit, fahkri dan agus tahun 2018, indonesia.

Desain industri :

Reog memiliki desain yang terlihat sangat kokoh dengan menggunakan chasis alumunium dan ditambah lapisan matte yang melindungi chassis nya terbebas dari sidik jari pengguna.

Spesifikasi reog:

1. Prosesor : intel core i7 3770K

2. Motherboard : ASUS Sabertooth Z77

3. VGA :Gigabyte GTX690

4. RAM : DDR3 intel extreme 32GB

5. Hardisk : western digital 1TB carivar black.

6. SSD : OCZ vector $256 \mathrm{~Gb}$

7. DVD room : Samsung

bluray combo SE-406B
8. Chassis : alumunium matte

9. Cooler/Kipas : Corsair $\mathrm{H} 100 \mathrm{i}$

10.PSU : Seasonic P860

Tata letak circuit :

Dapat dilihat mulai dari prosesor nya yang menggunakan core i7 yang notebene nya merupakan high prosesor, VGA nya berkelas, RAM nya $32 \mathrm{~GB}$, dan Hardisk nya mencapai 1TB dapat leluasa menyimpan game data lain yang cukup besar.

Rahasia dagang:

Yang membuatnya berbeda dari merk lain adalah lapisan chassis atau casing nya yang terbuat dari alumunium yang dilapisi matte yang terhindar dari sidik jari pengguna.

\section{B. STUDI REFERENSI ( SR )}

Pertanyaan Jenis B :

Jelaskan

pasal-pasal

pendukung didalam hak atas kekayaan intelektual

Jawaban :

Hukum Kekayaan Intelektual (HAKI) di bidang hak cipta memberikan sanksi jika terjadi pelanggaran terhadap tindak pidana di bidang hak cipta yaitu pidana penjara dan/atau denda, hal ini sesuai dengan ketentuan pidana dan/atau 
denda dalam UU No. 19 Tahun 2002 tentang Hak Cipta sebagai berikut:

Pasal 72 ayat (1) Barangsiapa dengan sengaja dan tanpa hak melakukan perbuatan sebagaimana dimaksud dalam Pasal 2 ayat (1) atau Pasal 49 ayat (1) dan ayat (2) dipidana dengan pidana penjara masing-masing paling singkat 1 (satu) bulan dan/atau denda paling sedikit Rp. 1.000.000,- (satu juta rupiah), atau pidana penjara paling lama 7 (tujuh) tahun dan/atau denda paling banyak Rp. 5.000.000.000,(lima miliar rupiah).

Pasal 72 ayat (2) : Barangsiapa dengan sengaja menyiarkan, memamerkan, mengedarkan, atau menjual kepada umum suatu ciptaan atau barang hasil pelanggaran hak cipta atau hak terkait sebagaimana dimaksud pada ayat (1) dipidana dengan pidana penjara paling lama 5 (lima) tahun dan/atau denda paling banyak Rp. 500.000.000,(lima ratus juta rupiah).

Pasal 72 ayat (3) : Barangsiapa dengan sengaja dan tanpa hak memperbanyak penggunaan untuk kepentingan komersial suatu program komputer, dipidana dengan pidana penjara paling lama 5 (lima) tahun dan/atau denda paling banyak Rp. 500.000.000,- (lima ratus juta rupiah).

Pasal 72 ayat (4) : Barangsiapa melanggar Pasal 17 dipidana dengan pidana penjara paling lama 5 (lima) tahun dan/atau denda paling banyak Rp. 1.000.000.000,- (satu miliar rupiah).

Pasal 72 ayat (5) : Barangsiapa dengan sengaja melanggar Pasal 19, Pasal 20, atau Pasal 49 ayat (3) dipidana dengan pidana penjara paling lama 2 (dua) tahun dan/atau denda paling banyak Rp. 150.000.000,(seratus lima puluh juta rupiah).

Pasal 72 ayat (6) : Barangsiapa dengan sengaja dan tanpa hak melanggar Pasal 24 atau Pasal 55 dipidana dengan pidana penjara paling lama 2 (dua) tahun dan/atau denda paling banyak Rp. 150.000.000,- (seratus lima puluh juta rupiah).

Pasal 72 ayat (7) : Barangsiapa dengan sengaja dan tanpa hak melanggar Pasal 25 dipidana dengan pidana penjara paling lama 2 (dua) tahun dan/atau denda paling banyak Rp. 150.000.000,(seratus lima puluh juta rupiah).

Pasal 72 ayat (8) : Barangsiapa dengan sengaja dan tanpa hak melanggar Pasal 27 
dipidana dengan pidana penjara paling lama 2 (dua) tahun dan/atau denda paling banyak Rp. 150.000.000,(seratus lima puluh juta rupiah).

Pasal 72 ayat (9) : Barangsiapa dengan sengaja melanggar Pasal 28 dipidana dengan pidana penjara paling lama 5 (lima) tahun dan/atau denda paling banyak Rp. 150.000.000,(seratus lima puluh juta rupiah).

Pasal 73 ayat (1) : Ciptaan atau barang yang merupakan hasil tindak pidana hak cipta atau hak terkait serta alat-alat yang digunakan untuk melakukan tindak pidana tersebut dirampas oleh negara untuk dimusnahkan.

Pasal 73 ayat (2) : Ciptaan sebagaimana dimaksud pada ayat (1) di bidang seni dan bersifat unik, dapat dipertimbangkan untuk tidak dimusnahkan.

\section{STUDI PENALARAN ( SP )}

Pertanyaan Kategori 3 :

Buatlah penjelasan secara detail dari produk Blackberry dan beberapa bagian HAKI yang ikut serta didalamnya

Jawaban :

BlackBerry adalah telepon seluler yang memiliki kemampuan layanan push email, telepon, sms, menjelajah internet, BlackBerry Messenger
(BBM), dan berbagai kemampuan nirkabel lainnya. BlackBerry pertama kali diperkenalkan pada tahun 1999 oleh perusahaan Kanada, BlackBerry.

Produk yang menjadi andalan utama dan membuat BlackBerry digemari di pasar adalah fitur surat-e cepat (push email). Produk ini mendapat sebutan surat-e cepat karena seluruh surat elektronik baru, daftar kontak, dan informasi jadwal (calendar) "ditampilkan" langsung ke dalam BlackBerry secara otomatis.

Seperti yang telah disebutkan di atas mengenai keunggulan dari BlackBerry, yaitu push e-mail. Dengan push e-mail semua surat elektronik masuk dapat diteruskan langsung ke ponsel. E-mail juga sudah mengalami proses kompresi dan scan di server BlackBerry sehingga aman dari virus. Lampiran berkas berupa dokumen Microsoft Office dan PDF dapat dibuka dengan mudah. Sebuah surat elektronik berukuran 1 MB jika diterima melalui push e-mail dapat menjadi $10 \mathrm{~KB}$ dengan isi yang tetap.

Pengguna tidak perlu mengakses Internet terlebih dulu dan membuka satu persatu surat elektronik 


\begin{abstract}
yang masuk, atau pemeriksaan surat elektronik baru. Hal ini dimungkinkan karena pengguna akan terhubung secara terus-menerus dengan dunia maya melalui jaringan telepon seluler yang tersedia. Alat penyimpanan juga memungkinkan para pengguna untuk mengakses data yang sampai ketika berada di luar layanan jangkauan nirkabel. Begitu pengguna terhubung lagi, BlackBerry Enterprise Server akan menyampaikan data terbaru yang masuk.
\end{abstract}

Kelebihan lainnya adalah kemampuan BlackBerry yang dapat menampung surat elektronik hingga puluhan ribu tanpa ada risiko hang, asalkan masih ada memori tersisa.

BlackBerry juga bisa digunakan untuk chatting. Mirip dengan Yahoo Messenger yang bernama BlackBerry Messenger (BBM) yang berjalan melalui jaringan BlackBerry dengan memasukan nomor identitas unik atau PIN dari setiap ponsel BlackBerry.

Semua layanan BlackBerry ini dikenal sangat aman, baik surat-e, chatting, maupun browsing. Untuk browsing Internet, data-data dari situs web sudah dikompresi sehingga lebih cepat dibuka.

Fasilitas lain yang menjadi andalan BlackBerry adalah pesan instan. Yahoo Messenger, Google Talk, dan Skype kini telah menjadi rekan BlackBerry. Teknologi terkini memang memungkinkan kita untuk mengobrol (chatting) di Internet melalui telepon genggam dan Personal Digital Assistant (PDA), tetapi yang berbeda pada BlackBerry adalah proses instalasi lengkap yang bisa dilakukannya melalui jaringan nirkabel.

Melihat fenomena BlackBerry yang digemari masyarakat karena keunggulan fasilitas komunikasinya, membuat banyak perusahaan IT berkembang dan berlombalomba menciptakan aplikasi yang paling mutakhir untuk pengguna BlackBerry. Keunggulan lain juga hadir melalui teknologi kompresi yang menyebabkan biaya akses menjadi murah dan pemberitahuan jawaban pesan melalui tanda getar pada BlackBerry. Penggunaan BlackBerry semakin meluas dengan hadirnya fasilitas koneksi BlackBerry (BlackBerry Connect). Dengan BlackBerry Connect, pengguna tidak lagi harus menggunakan perangkat 
genggam BlackBerry untuk memanfaatkan BlackBerry Internet Solution. Pengguna hanya perlu menginstalasi BlackBerry Connect pada smartphone merek apapun yang dimiliki, sehingga bisa memanfaatkan BlackBerry Internet Solution.

Spesifikasi BlackBerry Torch Pembuat : BlackBerry Jaringan

GSM850/900/1800/1900

GPRS/EDGE/UMTS

CDMA/1xEV-DO iDEN

Dimensi : $50 \mathrm{~mm} \times 106.7$

$\mathrm{mm} \times 14.5 \mathrm{~mm}[1]$

Berat : $87.9 \mathrm{~g}$ to $155 \mathrm{~g}$ dependent upon model

Memori : $64 \mathrm{MB}$ to $1 \mathrm{~GB}$ dependent upon model

Layar : $480 \times 360$ pixels (Curve 8900/Tour 9630/Bold 9700) $360 \times 480$ pixels (Storm) $480 \times 320$ pixels (Bold) $320 \times 240$ pixels

(8300/8700/8800/8500

Series) $240 \times 260$ pixels $(7100 / 8100$ Series) $240 \times$ 320 pixels (8200 Series) 65,000 colors

Nada dering : Poliphonik, MP3, MIDI

Konektivitas : microSD, USB, Bluetooth, WiFi, GPS

BlackBerry berbeda dengan produk lainnya, produk selain BlackBerry aplikasinya membutuhkan koneksi GPRS/EDGE/3G maka koneksi akan dikenakan biaya GPRS sesuai operator. Jumlah surat elektronik yang bisa diintegrasikan jika menggunakan ponsel BlackBerry adalah 10 akun surat-e dan jika menggunakan BlackBerry Connect tergantung memori HP.

Model Awal : 850, 857, 950, 957. Model Monokrom berbasis Java : seri 5000 dan seri 6000 . Model Warna : seri 7200 , seri 7500 dan seri 7700. Model dengan kemudahan mengetik : seri 7100. Model BlackBerry Modern : seri Huron (8800), termasuk BlackBerry Pearl (8100) dan BlackBerry Curve (8300) Model Terkini (2008- ..) : Seri Bold (9000), Pearl Flip (8220), Storm (9500), Javeline (8900), dan Gemini (8520) BlackBerry Bold 9700 dan BlackBerry storm II, lalu yang terbaru adalah BlackBerry 9900, BlackBerry 9930.

Pada Januari 2011, Blackberry dan Research In Motion (RIM), perusahaan induknya asal Kanada, menjadi topik utama di pemberitaan Indonesia, setelah Menkominfo Tifatul Sembiring mengultimatum untuk mencabut izin mereka di Indonesia karena tuntutan pemerintah untuk memblokir pornografi tidak dipenuhi. 
Tuntutan lainnya yang tidak dipenuhi adalah pemindahan data center dari Kanada ke Indonesia. Pemerintah Indonesia melalui Menkominfo menyatakan bahwa dengan kondisi data center tetap di Kanada, setiap tahun RIM berpotensi mendapat pemasukan sekitar Rp. 2 Triliun tanpa terkena pajak dari Indonesia. Desakan ini didukung banyak pihak, antara lain oleh Komisi Pemberantas Korupsi, Ketua Komisi I DPR Mahfudz Siddiq, Ketua Umum International Conference of Islamic Scholars (ICIS) Hasyim Muzadi,Yayasan Lembaga Konsumen Indonesia, dan Kepolisian Republik Indonesia.

\section{REFERENSI}

[1] A. S. Putra And O. M. Febriani, "Knowledge Management Online Application In Pdam Lampung Province," In Prosiding International Conference On Information Technology And Business (Icitb), 2018, Pp. 181-187.

[2] A. S. Putra, O. M. Febriani, And B. Bachry, "Implementasi Genetic Fuzzy System Untuk Mengidentifikasi Hasil Curian Kendaraan Bermotor Di Polda Lampung," J. Sist. Inf. Dan Manaj. Basis Data, Vol. 1, No. 1, Pp. 21-30, 2018.
[3] O. M. Febriani And A. S. Putra, "Sistem Informasi Monitoring Inventori Barang Pada Balai Riset Standardisasi Industri Bandar Lampung," J. Inform., Vol. 13, No. 1, Pp. 90-98, 2014.

[4] Putra, Arie Setya. "2018 Artikel Struktur Data, Audit Dan Jaringan Komputer." (2018).

[5] Putra, A. S. (2018, July 17). Paperplain Fundamental Create Application With Borland Delphi 7.0 University Of Mitra Indonesia. Retrieved From Osf.lo/Pbrn9. 